\title{
Przeżycie, przestrzeń, obraz. Publiczność a okoliczności epoki
}

Agnieszka D. Kawka 


\section{AGNIESZKA DOROTA KAWKA}

\section{Przeżycie, przestrzeń, obraz. Publiczność, a okoliczności epoki}

Jednym z elementów składowch teatru jest publiczność. Musi być w teatrze ktoś, kto prezentuje fabułę, prowokuje pewien typ odbioru - aktorzy, i ktoś, kto ogląda, obserwuje, śledzi akcję i reaguje - publiczność. Publiczność znajduje się w określonej przestrzeni teatralnej. I tak jak różnorodna bywa owa publiczność, tak istnieją różne wymiary i płaszczyzny przestrzeni.

Informacja: formalna, treściowa i wizualna, płynąca ze sceny powoduje reakcje widza. Rodzaj tej informacji zależy od tendencji filozoficznych i artystycznych danej epoki. Stąd różne sposoby, metody - prezentacji - docierania do widza i różne jego reakcje.

To „okoliczności” społeczne, filozoficzne, polityczne i estetyczne epoki kreują przestrzeń teatralną i determinują sposób reagowania widza. To one „umieszczają" widza w określonym miejscu zarówno w owej przestrzeni, jak też w hierarchii wartości - dają mu albo władzę, siłę, albo traktują przedmiotowo jak „pionka w grze": wymuszają na nim rodzaj przeżycia wewnętrznego i prowokują do określonych zachowań zewnętrznych. Dlatego właśnie będziemy tu mówić o „okolicznościach" teatralnych: przestrzeni i przeżyciu, o publiczności i epoce.

Ciąg naczyń polączonych, nieustanny dialog między dramaturgiem (przecież tworzącym swoje dzieło w określonej epoce - a więc w znacznym zakresie wyrazicielem jej ideologii) a widzem (również charakterystycznym dla danego czasu), dialog w którym swoiste medium, przekaźnik stanowi inscenizacja reżysera i gra aktorów zamknięta przestrzenią tworzy materię, strukture sceniczną, tworzy teatr.

Zastanówmy się nad odbiorem tego teatru. Należy rozgraniczyć dwa typy oddziaływania ze sceny. Pierwszy to ten, który powoduje u widza rodzaj wewnętrznego przeżycia, drugi to ten, który dociera do widza przez swoją 
wizualność, przez obrazy. Można więc mówić o "przeżywaniu” i o „oglądaniu".

Stanisławski i Meyerhold rozmawiali o wystawieniu Don Juana Mozarta. Kiedy Meyerhold powiedział, że jego zdaniem, w operze powinno być przynajmniej piętnaście - osiemnaście obrazów, Stanisławski przerwal mu: „Mało! Dwadzieścia, dwadzieście pięć!". Meyerhold natychmiast zgodził się i dodał: "Ale powinny się zmieniać błyskawicznie". Bo w innym razie spektakl zrobi klape"'1.

Meyerhold pokazywał więc ze sceny szybko zmieniające się obrazy. Jego spektakle odwiedzały tłumy. Na jakiej zasadzie oddziaływał na publiczność?

Wywoływał poczucie wspólnoty. Pokazywał, ilustrował treści i wymagał bacznej obserwacji. Na jego spektaklu widz ogląda i jednocześnie czuje wspólnotę z drugim, siedzącym obok uczestnikiem. Widzowie są tu jakby całym światem, wszystkimi ludźmi.

„Główna zaleta - to aktualność, Meyerhold trafił w dziesiątkę, w samo sedno wewnętrznych potrzeb wspólczesnej widowni. Odgadł istotę tych potrzeb, odpowiedział na nie wypowiedziane pytania, na nie uświadomione pragnienia szerokich mas widzów"2.

"Zakończyły się przygotowania i na salę wpuszczono publiczność. Widzowie z pierwszego rzędu byli mocno zdziwieni, że tuż koło ich nóg wznosi się wielka półkula przedstawiająca glob ziemski. Scena była bezpośrednio połączona z widownią.

Po wystąpieniu przedstawiciela komisji pierwszomajowej, który mówił - międzynarodowym święcie mas pracujących, zgasło i znów zapaliło się światło. Na proscenium wyszedł aktor $w$ niebieskim roboczym ubraniu, grający rolę Parobka. Powiedział pierwsze słowa prologu:

\section{Za minute pokażemy wam...}

Pogroził publiczności pięścią i po krótkiej pauzie jak gdyby z pewną ulgą (nie takie to straszne) zakończył fraze -

\section{Misterium buffo"3.}

"Misterium - buffo wywarło ogromne wrażenie nie tylko na widzach, obecnych na premierze. Byłem na kilku przedstawieniach i za każdym razem widziałem, w jak silny sposób sztuka oddziałuje na publiczność. Było to

' J. Bachruszyn, Stanislawski i Meyerhold, w: Spotkania z Meyerholdem, przelożył E.P. Melech, Warszawa 1981, s. 341.

${ }^{2}$ B. Zachara, Dwa Sezony (1929-1925) w: Spotkania z Meyerholdem, op. cit, s. 115.

${ }^{3}$ A. Fiewralski, Na początku lat doyudziestych w. Spotkania z Meyerholdem, op. cit., s. 51. 
spowodowane przede wszystkim tym, co w owych czasach stanowiło jeszcze ewenement: na scenę przeniesiono wydarzenia i słowa wzięte z życia rewolucyjnego kraju. Sila oddziaływania spektaklu była oczywiście w ogromnym stopniu wynikiem samej sztuki i nowatorstwa inscenizacji" - pisał Aleksander Fiewralski ${ }^{4}$.

Meyerhold opowiada historie aktualne, dotyczące teraźniejszości. Używa do tych opowieści bardzo doniosłych środków wyrazu. Chce szokować pomysłami inscenizacyjnymi. $W$ jego teatrze grano na tle gołych ścian, na surowych kubistycznych konstrukcjach. W Jutrzniach scenę wypełniały walce, cylindry, dyski, kręcone schody, maszty, liny. Rampa została zniesiona. Scenę złączyło z widownią obszerne półkoliste proscenium, nawiązujące do greckiej orchiestry.

Spektakle Mayerholda nazywano wiecami politycznymi. Śpiewano na nich Międzynarodówkę. Znany jest fakt, że aby pobudzić widzów reżyser wprowadził na salę oddział wojska. Rozsadzeni wśród widzów żołnierze klaskali, hałasowali, podejmowali okrzyki chóru aż wreszcie weszli na scenę i spektakl przeistoczył się $w$ wiec. Na zakończenie przemówił Meyerhold ${ }^{5}$.

Widz był „poruszany" i ,zaczepiany” przez Meyerholda. Atakowano go aktualnością, angażowano do fizycznego - zewnętrznego współuczestnictwa. Prowokowano jeden wspólny model zachowania. Aplauz albo dezaprobata. Krzyki albo śmiechy. Wspólne gesty, wspólne myśli.

Przykład jest rzeczywiście jaskrawy. Ale czy pokazuje on jedynie zastosowanie metody politycznego wiecu w teatrze? Chyba nie. Reżyser tak przedstawiał aktualne treści, tak "rozczulal" widzów, że jednoczyli się $z$ bohaterami.

„Aksjusza ze spektaklu Meyerholda - to człowiek pracy. Widzieliśmy jak maglowała bieliznę, jak rozwieszała tę bieliznę na podwórzu, nakrywała do stołu na przyjęcie gości - wydawało się, że ani chwili nie może usiedzieć spokojnie. A jeśli nawet znajdzie odrobinę wolnego czasu, wypełnia ją energicznym, radosnym ruchem $w$ karkołomnym locie karuzeli... Wspaniała dziewczyna. A to, że $w$ trakcie rozmowy z Bułanowem szybko porusza się po scenie rozwieszając bieliznę i niedbale opowiada mu przez ramię, podkreślało jeszcze dodatkowo jej pogardę dla Bułanowa, co z kolei zapewniało jej sympatię radzieckiej publiczności. (...) Ani na moment nie opuszczało Meyerholdowskiej Aksjuszy poczucie godności i wewnętrznej swobody. To właśnie tak bardzo radowało ówczesną widownię"6.

Nie zajmuję się tu analizą twórczości teatralnej Meyerholda. Pragnę jedynie pokazać sposób oddziaływania na publiczność. Adresatem spektaklu jest całe społeczeństwo. I publiczność to czuje. Efekty wizualne, gigan-

\footnotetext{
${ }^{4}$ A. Fiewralski, op. cit., s. 52.

${ }^{5}$ K. Braun, Wielka reforma teatru w Europie ludzie - idee - zdarzenia, Wroclaw 1984, s. 223.

${ }^{6}$ B. Zachara, op. cit., s. 117.
} 
tyczność środków, szybkość zmiany obrazów, aktualna fabuła oraz inne opisane środki, wywołuja $w$ widzach odczucia ponadczasowości. Tak to zostaje zburzona struktura budynku teatralnego. Widz ogląda obrazy $i$ jednoczy się z sąsiadem siedzącym obok. Publiczność jest monolitem. Meyerhold osiąga to za pomocą i dzięki wizualności i niemal nadrzędnej aktualności.

Gautier mógł rzeczywiście napisać: „Nadszedł czas widowisk czysto wzrokowych", a w Akademii Muzyki jak i na wszystkich innych ówczesnych scenach, jednym z najważniejszych elementów scenicznych miała się odtąd stać dekoracja?.

I tak dekoracja oraz to, że można wprawić ją w ruch stają się jednym z najważniejszych wyznaczników teatru. Jaka była publiczność tego okresu?

Fragment, który zacytuję, opisuje zachowania publiczności teatrów bulwarowych, tych najpopularniejszych, ale zarazem określa w pewien sposób tendencje i kierunek ewolucji teatru. „Zainteresowanie sztuką dramatyczną mierzyło się zatem u widzów tylko liczbą „obrazów». Im spektakl miał więcej obrazów, tym więcej posiadał szans, że się spodoba. Inne perypetie, ciągle zmiany dekoracji, skomplikowane efekty maszynerii, operowanie tłumem, świeżość kostiumów - oto, czego żądali bywalcy drugorzędnych teatrów, którzy pragnęli przede wszystkim wrażeń wzrokowych"8.

I dalej w cytowanej przeze mnie książce czytamy: „Cztery ówczesne teatry "Gaité», »Porte-Saint-Martin«, »Cyrk Olimpijskiu i »Ambigu - Comique», stale ze sobą rywalizowały w prezentowaniu dekoracji, kostiumów, "tricków", maszynerii mających ilustrowaś wielkie widowiska, których złożoność z trudem możemy sobie wyobrazić. Era nowoczesna teatru - pisze Challamel - zaczyna się w "Gaité» (dyrekcja de Pixerecourta), gdzie aklimatyzują się melodramaty widowiskowe polączone ze śpiewami, tańcami, walkami na scenie, pantonimami... Rośnie liczba statystów. Rekwizyty wypełniają wszystkie magazyny. Trzeba tu raczej spektaklu dla oczu niż dla uszu. Sztuki z efektami są górą"9. Oto czym teatr był dla widza i w jaki sposób, jako instytucja, starał się oczekiwania widza zaspokoić.

Dla dopełnienia tego obrazu warto przytoczyć pogląd Goethego zawarty w Prologu do Fausta. Jest to spojrzenie na teatr romantyczny oczyma twórcy dramatu, czyli tego, który dostarcza tworzywa dla aktorów, reżysera i publiczności.

\footnotetext{
${ }^{7}$ M.A. Allévy-Viala, Inscenizacja romantyczna we Francji, Warszawa 1958, s. 86.

8 lbid., s. 87.

${ }^{9}$ Ibid., s. 88. 
Thumowi chciałbym przysporzyć ochoty (...)

Tłum za patrzeniem jedynie szaleje.

Gdy przed oczyma tyle się rozgrywa

By każdy mógł się nagapić do syta

Na pewno przyszłość czeka was szczęśliwa (...)

Zachcenia mas jedynie masą się ukróci (...)

Więc na dzisiejsze przedstawienie

Niech maszynami się szafuje.

Dajcie horyzont mały, wielki

Gwiazdami zapełnijcie nieba.

Wody i ognia w bród potrzeba

Pokażcie ptaki i stwór wszelki.

Takim sposobem w sceny ciasne ramy, okręg stworzenia pomieście nam cały

1 krok kierujcie w roztropności śmiały

$Z$ nieba przez świat tam aż do piekieł bramy ${ }^{10}$.

W kilkunastu wierszach nakreślony został obraz romantycznego widza. Koncepcje artystyczne epoki implikują dla kogo i w jaki sposób mają być grane spektakle. I nie jest teatr romantyczny teatrem politycznym.

Allèvy-Viala opisując narodziny teatru romantycznego i sytuację społeczną towarzyszącą tym narodzinom, pisze: „Życie teatrów zawsze będzie ściśle zależne od ustroju społecznego, gdyż te publiczne instytucje znajdują się pod mniej lub bardziej bezpośrednią kontrolą państwa, narzucającego im ich statut administracyjny i w konsekwencji warunki ich egzystencji i działania. Zmiany ustroju społecznego powodują więc często głębokie przeobrażenia w organizacji spektakli"...11

Allèvy pisze o ogromnej potrzebie spektaklu, która wówczas się u widzów pojawila. O tym, że odnajdujemy ją również w samej budowie ówczesnych sal widowiskowych, w wielkiej glębi, jaką architekci dali scenom.

"Okoliczność ta sprzyja dekoracji i maszynerii; warto pod tym względem zapoznać się z makietą pokazującą szczegóły maszynerii drugiej sali. „Palais-Royal« (1770), zrekonstruowany w Muzeum Opery. Czyż nie odnajdziemy tego samego $w$ owym okrągłym lub owalnym kształcie przyjętym dla sal niegdyś prostokątnych lub kwadratowych? (okoliczność potrzebna ze względu na widzialność). ${ }^{\text {"12 }}$

Pisarze byli pod ogromnym wpływem możliwości teatru. Nasi dramaturdzy - Mickiewicz, Słowacki - oglądali wielkie paryskie spektakle. Odnaj-

\footnotetext{
10 Ibid., s. 92.

11 Ibid., S. 31.

12 Ibid., s. 33.
} 
dujemy ich ślady w wielu utworach. Znane jest sformułowanie Mickiewicza, że "w dramacie poezja przechodzi w działanie wobec widzów" "13. Volltaire często sięgał w swoich utworach po "wszystkie sceniczne akcesoria melodramatu (...) zjawy, błyskawice, grzmoty, ruchliwość tłumu'14. Czytamy jeszcze u Allévy Viala:

A ",...) Serwandoni [ówczesny inscenizator - A.D.K.] starał się naśladować wszystkie zjawiska natury: deszcz, błyskawice, grzmot, efekt wrzącej wody itd. Wezwany do Opery, by "olśniewać oczy, zachwycać spojrzenia, zadziwiać - dzięki udoskonalonej maszynerii i śmiałym efektom - widzów«, których nie czarowały wiersze ani muzyka (...)"15.

Publiczność była zadowolona. Jeszcze w drugiej polowie XVIII w. teatr był sztuką przeznaczoną dla świata ludzi uprzywilejowanych: bogaczy, intelektualistów, ludzi wykształconych. Wkrótce, jak pisze Zbigniew Raszewski epoka ta „wytworzyła widowsko, którym pasjonowaly się wszystkie środowiska, od królów i cesarzy po tłumy robotników ściągających do przedmiejskich teatrów Paryża i Londynu"16.

Teatr romantyczny jest mniej zaangażowany w politykę niż teatr Meyerholda. Czasy są też inne. Jest jednak osadzony mocno w życiu społecznym. Ale mechanizm i efekty oddziaływania na widza są podobne. Spektakl ma go zaszokować, jakby oślepić, zwraca się do wszystkich i u wszystkich chce wywołać określony typ zachowania. Teatr romantyczny jakby chciał widza „stłamsić", , przydusić”, ,przycisnąć" do muru, „zatkać mu usta”, a jednocześnie pozwala się zabawić, prowokuje swobodą zachowania, pokazuje mu obrazy i chce wywołać poczucie jedności i wspólnoty.

W przytoczonych przykładach teatr posługiwał się obrazem, a jego adresatem czynił wszystkich ludzi. W kolejnych, glówny akcent przeniesie się na przeżycia jednostek. Odbiorcą będzie nie tlum, lecz elita. I sprawa, która ich - widzów - łączy, będzie szczególna, jedna, jedyna. W poprzednio opisanych przykładach widz to zbiorowość zjednoczona odczuciem wspólnoty. Stanowi ona monolit również $w$ sensie przestrzennym. Pojęcie tłumu odchodzi w niebyt, a najważniejsze staje się to, co przeżywa każdy z osobna. I tak jak poprzednio celem było narzucenie jednego stylu zachowania, tak teraz mamy do czynienia z ich mnogością - tyle sposobów odbioru, ilu widzów. Każdy ma prawo do indywidualnego przeżycia, które wzmaga i zabarwia rozbudzone przy tej okazji poczucie elitarności.

\footnotetext{
${ }^{13}$ Z. Raszewski, Krótki zarys historii teatru, Warszawa 1978, s. 104.

${ }^{14}$ M.A. Allévy-Viala, op. cit., s. 35.

${ }^{15}$ M.A. Allévy-Viala, op. cit., s. 34.

${ }^{16}$ Z. Raszewski, op. cit., s. 103
} 


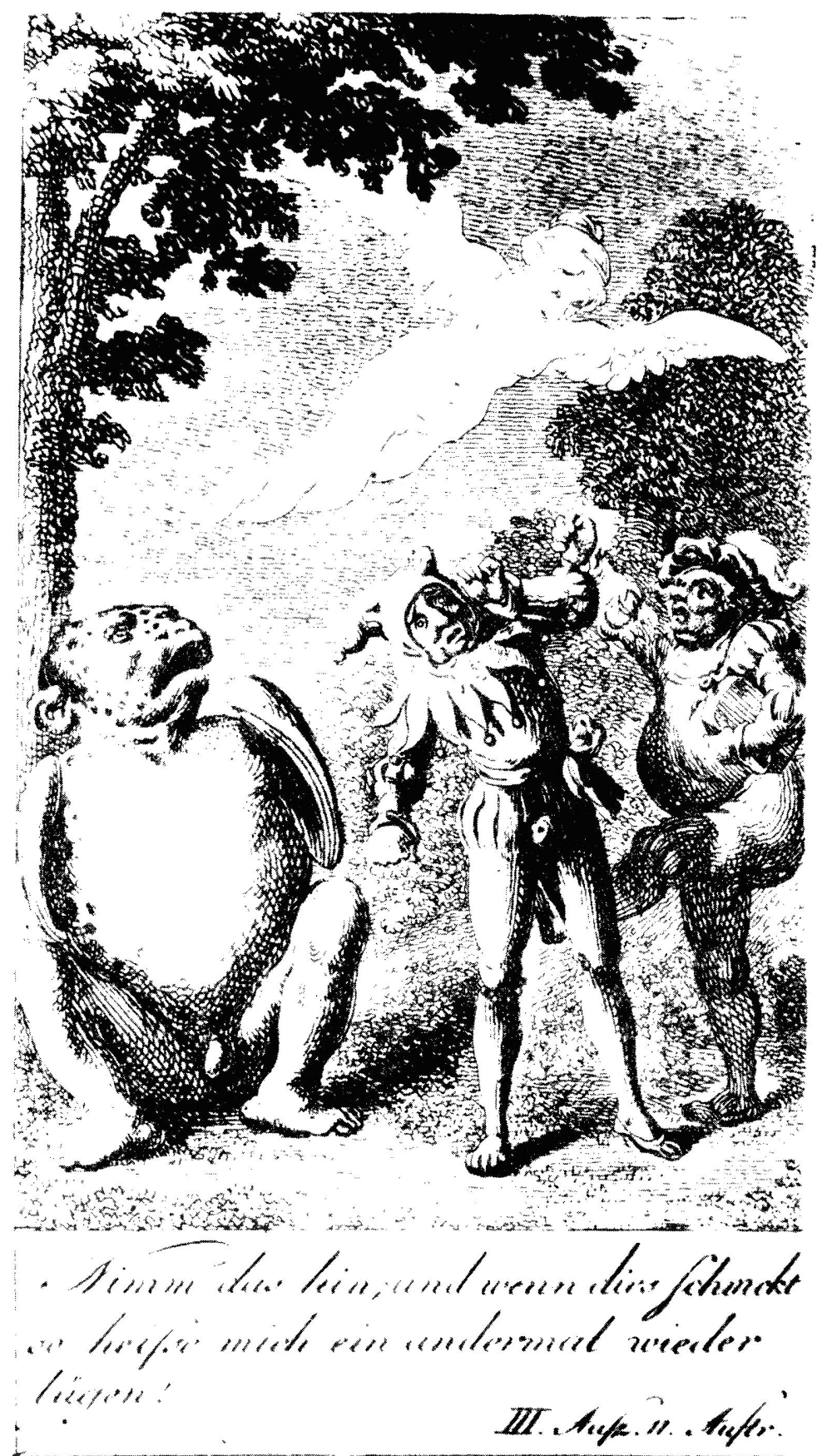

Rys. 9. Daniel Chodowiecki: Ilustracja do „Burzy” Szekspira. 1\%/ http://rcin.org.pl 
Widzów łączy wspólne przeżycie i wspólna idea. Oni są tymi wybranymi, którzy znajdują się właśnie tu, teraz i w tym miejscu. Kiedy teatr odwołuje się do odczuć, prowokuje przeżycie, to zwraca się do szczególnego odbiorcy. Do tego, który ma wierzyć albo już uwierzył, tak jak to się dzieje, np. w spektaklach misteryjnych Nawiedzenia grobu, w Średniowieczu. A także do tego, który jest po właściwej stronie i przeciwko tym, co nie z nim, tak jak to się dzieje np. w przedstawieniach Bogusławskiego.

$Z$ przeżywaniem w tym typie spektakli łączy się pojęcie uczestnictwa. Możemy je np. współcześnie zaobserwować w poczynaniach stowarzyszenia teatralnego Gardzienice. Jest to jakby kliniczny przyklad teatru realizowanego wedle tej formuly.

Elitarność prowokowana przez wydarzenia polityczne była jednym z ważnych elementów teatru stanu wojennego. Nie był on otwarty i dostępny dla każdej publiczności. Ale łączył tych, którzy byli „przeciwko".

Jak działał ów mechanizm w teatrze średniowiecznym?

Nawiedzenie Grobu (Visitatio Sepulchri) to średniowieczna forma teatralna odnaleziona w Polsce, którą możemy nazwać dramatem liturgicznym. O swoistej dramaturgii tego tekstu świadczą te elementy, które predestynują tekst do „odgrywania", przedstawiania publiczności za pomocą głosu, gestu, kostiumu.

Cztery wersje Visitatio Sepulchri, zamieszczone w Dramatach staropolskich pod red. Juliana Lewańskiego ${ }^{17}$, są zapisem jednego z głównych obrzędów religii chrześcijańskiej - $z$ jednoczesnym dostosowaniem go do odegrania w kościele. Visitatio Sepulchri odprawiane było w Polsce mniej więcej od połowy XIII wieku (na pewno przed rokiem 1253). Tekst anonimowego autora jest zabytkiem piśmiennictwa średniowiecznego $w$ języku łacińskim.

Tekst ma wyraźną budowę dialogową. Składa się z 11 wypowiedzeń, $z$ których każde opatrzone jest swoistym komentarzem odautorskim, mającym charakter zarówno wskazówek dotyczących gry aktorskiej, miejsca i czasu akcji, jak również zapowiedzi kwestii wypowiadanych przez poszczególnych aktorów. Stanowi to podstawowy element dynamizujący akcję.

Bezpośrednio z tekstu dowiadujemy się więc, że akcja rozgrywa się w środkowej części kościoła. Jedni aktorzy (konwent braci) przybywają tam z prezbiterium, drudzy (trzej bracia odgrywający role trzech Marii) wprost z zakrystii kierują się w stronę Grobu. Święty Grób - centralny element

17 J. Lewański, Dramaty Staropolskie.Warszawa 1963. 
scenografii znajdował się w różnych miejscach Kościoła. „Często grób urządzano podnosząc po prostu płyte zakrywającą zejście do krypty znajdującej się zwykle pod prezbiterium. Płyta stawała się od razu dekoracją - kamieniem cudownie odwalonym"18.

W poczet aktorów należaloby zaliczyć także "dwóch chłopców", pełniących role strażników Grobu, prawdopodobnie kleryków lub uczniów, należących do schola cantorum znajdującej się przy katedrze.

W dalszej części utworu pojawiają się kolejni dwaj aktorzy, określani przez autora: „dwaj spośród braci". Te dwie postacie interpretuje się jako św. Piotra i św. Jana. Ważką postać stanowi też Kantor - dyrygent chóru. On to bowiem intonuje psalmy, hymny i antyfony, on rozpoczyna i kończy "spektakl".

Analizując owe komentarze odautorskie, będące jak gdyby pierwowzorem scenariusza, można wydzielić cztery autonomiczne odcinki treściowe, których wyznacznikiem wydaje się być pojawienie poszczególnych aktorów:

1) Przejście konwentu braci z prezbiterium na środek kościoła; powtarza responsorium,

2) Przejście braci odtwarzających role Marii z zakrystii w stronę Grobu

a) dialog ze strażnikami,

b) wejście do Grobu i okadzenie go; przejście ze śpiewem przez prezbiterium do zakrystii,

3) Pojawienie się św. Piotra i św. Jana i ich „bieg" do Grobu,

4) Powrót do prezbiterium i ukazanie całemu ludowi - publiczności - całunu i chusty.

Z tego swoistego planu wydarzeń - krótkiego zapisu odsłon - można się zorientować, iż akcja - mimo jej centralnego usytuowania wokół Grobu - jest bardzo dynamiczna. Aktorzy posuwają się z jednego miejsca w drugie, a następowanie po sobie kolejnych odsłon wydaje się być następstwem wprowadzania do gry nowych person. Kulminacyjnym punktem przedstawienia jest z pewnością ostatnia jego część, kiedy to święci przekazuja zgromadzonej publiczności dowody cudownego zmartwychwstania Jezusa Chrystusa - caluny i chustę. Użycie tego rekwizytu powoduje niewątpliwy wzrost temperatury na widowni.

W zapiskach "dramaturga" znajdziemy również wiele wskazówek dotyczących sposobu gry aktorów, gestykulacji, kostiumów, a także scenografii. Postacie dramatu występowały zapewne w szatach liturgicznych.

Podczas obrzędu aktorzy posługują się obrzędowymi liturgicznymi rekwizytami, które spelniają tu funkcje uteatralniające. Zapach i dym kadzidel potęgował na pewno wrażenia, działał na zmysły. Rekwizytami o znaczeniu 
centralnym są całuny i chusta. Przez swój bezpośredni związek z ciałem Chrystusa posiadają niezwykle emocjonalne wartości dla ludzi zgromadzonych w Kościele. Wyjście z owymi całunami do ludzi wytwarza atmosferę świętości, a jednocześnie bliskości rekwizytu.

Autora-dramaturga interesuje także sposób gry aktorskiej: modulacja glosu, prowadzenie dialogu, ustawienie postaci czy gestykulacja. Najważniejszymi punktami scenograficznymi - czyli miejscami akcji - są: prezbiterium, zakrystia i Grób. Jak pisze J. Lewański ,....ten centralny element wystroju dekoracyjnego był corocznie konstruowany. Wiadomo o tym, że montowano coś $w$ rodzaju namiotu $z$ drogich tkanin, które do ziemi przyciskano kamieniami. Na tych kamieniach w czasie udramatyzowanego obrzędu Depositio Crucis (złożenia do Grobu) w Wielki Piątek, po złożeniu w grobie krucyfiksu, kładziono pieczęcie... Na śodku znajdowała się zapewne tumba grobowa, a na niej całun i druga biala chusta... w którą owijano glowe Ukrzyżowanego"19.

Jak podaje Lewański, tworzywem literackim Visitatio Sepulchri była Ewangelia św. Marka, a także średniowieczne legendy i apokryfy. Poszczególni aktorzy porozumiewają się między sobą odśpiewując swoje partie, używają w tym celu dwóch, znanych w religii chrześcijańskiej figur: antyfony i wersetu.

Szczególnie ważna jest antyfona - krótka pieśń poprzedzająca w czasie obrządku liturgicznego śpiew psalmu i powtarzana po jego odśpiewaniu, w Nawiedzeniu Grobu, funkcjonująca jako pieśń samodzielna.

Historia życia i śmierci Zbawiciela - Jezusa Chrystusa - jest pierwowzorem prób dramatycznych zarówno poprzez zastosowanie środków liturgicznych charakterystycznych dla nabożeństw chrześcijańskich, jak i wprowadzenie widowiskowego nastroju i atmosfery odświętności, wynikającej z samego obrządku religijnego. Trzeba także pamiętać, iż te „obrzędy" teatralne związane były z głównymi świętami Chrześcijan: Wielkanocą i Bożym Narodzeniem. Związek ten wyraził się zarówno w dochowaniu wierności czasów akcji, w którym wydarzenia biblijne się rozgrywały, jak i w samej scenerii i autentyczności postaci - bohaterów dramatu.

Powszechny, spontaniczny udział w obrzędach ma swoje odzwierciedlenie we wspólnym śpiewie (w początkowym okresie jedynym), wspólnej procesji i wspólnym przeżyciu, wynikającym przede wszystkim z faktu, iż uczestników obrzędu łączyła wiara. Widzowie niewątpliwie podlegali pewnemu osobistemu przeżyciu, poddawali się obrzędowi, uczestniczyli emocjonalnie w spektaklu. Jakimi środkami posługiwał się ten teatr? Rekwizyt służy tu do unaocznienia zjawisk, które kiedyś już się odbyły, do przypomnienia ich, do ponownego przeżycia. Nie obrazy tu są najważniejsze, ale te

${ }^{19}$ J. Lewański, Dramat i teatr średniowiecza... Op. cit., s. 58. 
inne czynniki, które mają na celu wywołać psychologiczny związek z widzem. To wymienione już ,autentyczne" rekwizyty, szaty liturgiczne, wreszcie zdarzenia, prowokujące emocje.

Podobny mechanizm przeżycia teatralnego, choć nie taki sam, można zaobserwować w teatrze Bogusławskiego, w okresie tworzenia się Sceny Narodowej.

„W 1791 z powodzeniem gra się komedię Wybickiego Szlachcic mieszczaninem, znamienny obraz pojednania dwóch stanów. Jeszcze większą sensacje budzi Powrót posła Niemcewicza. Zgodnie z dobrze wypróbowanym schematem publiczność ujrzala tu dwie postawy wcielone w postaci dwóch rywali. Zwycięstwo odnosił kawaler, wąsaty i w kontuszu, jak to już wielokrotnie bywało, po raz pierwszy jednak z poszanowaniem tradycji łączący upodobania do reform społecznych i politycznych. Rzecz godna uwagi, że tak opracowany wariant wywołał protesty na widowni i poza nią (nawet na forum sejmowym), ale już tylko wśród opozycji, malejącej z dnia na dzień. Reszta oklaskiwała go owacjami. Od dnia premiery (15) do uchwalenia nowej Konstytucji ( $3 \vee 91$ ) Powrót posła osiągnął czy nawet przekroczył liczbę 10 przedstawień, zawrotną na owe czasy"20.

Tyle opis przedstawienia, które przecież nie jest grane dla wszystkich, powstaje niejako $w$ opozycji do kogoś $i$ do czegoś. Publiczność, to wybrańcy, patrioci, elita. To ci, którzy wiedzą lepiej od innych. Są to ludzie, którzy w trakcie spektaklu (i nie tylko) angażują się w pewną słuszną ideę. To okoliczności polityczne epoki wpływają na to, że teatr staje po "słusznej" stronie. Te okoliczności wymuszają pewien typ reakcji na publiczności.

Raszewski pisze „(...) można mówić o nowej odmianie życia teatralnego. $W$ ciągu całego pięciolecia teatr będzie $w$ starciu z przeciwnikiem, coraz groźniejszym. Czym jednocześnie będzie pogłębiał porozumienie z większością. Fakt, że większość sama jest żądna zmian (w historii spoleczeństwa epokowy) w dużej mierze tłumaczy liczbę innowacji" ${ }^{21}$.

Bogusławski stosował dla pobudzenia publiczności różne metody: na jego spektaklach wyrzucano ulotki - patriotyczne - korzystano z metod agitacyjnych. „Przekazy z epoki, mówiące o oddziaływaniu utworu w marcu 1794 są wyiątkowo zgodne. W żadnym z nich nie ma słowa na temat ugodowości, za to wszystkie mówią o jego roli agitującej do zbrojnej walki: rzecz była »do przypadku« napisana i zachęcała do powstania miała sarie, zupełnie do okoliczności stosowne, a bardziej zapalające. Operetka ta była

20 Z. Raszewski, op. cit., s. 71.

${ }^{21}$ Z. Raszewski, op. cit., s. 72. 
początkiem i rozgrzała umysły do przyszłej rewolucji«. Trzy z różnych źródeł relacje o tym, że utwór krył w sobie przebieg rewolucji, przytaczano już wyżej"22.

Należy podsumować dotychczasowe rozważania.

Okoliczności społeczne, polityczne, filozoficzne, estetyczne epoki warunkują typ publiczności, która przychodzi do teatru. W przedstawionych przykładach można zauważyć dwa typy reakcji odbioru przedstawienia: wizualnego uczestnictwa $\mathrm{i}$ indywidualnego przeżycia. Pierwszy sposób wywolany zostal poprzez pokazywanie akcji, obrazowanie fabuły, przy zastosowaniu wielu środków wyrazu. W tym wypadku chodzi o „zabawienie" widza, o sprowokowanie, wciągnięcie go do uczestnictwa w spektaklu, spowodowanie podobnych reakcji i wywołanie poczucia wspólnoty. W drugim przypadku pojawia się u widza wewnętrzne przeżycie, sprowokowane bądź uczestnictwem w obrzędzie, gdzie symbolika religijna (są rekwizyty, szaty) sprawia, że angażuje się w wydarzenia, które już się odbyły, są zapisane w Biblii, albo widz powodowany uczuciami patriotycznymi czy innymi opowiada się po jakiejś stronie a przeciwko innej. Przy czym dominujące u widza jest odczucie elitarności $i$ indywidualizmu - szczególnie $w$ pierwszym przypadku. W drugim, obok elitarności i indywidualności odczuwa on stan wspólnoty (kiedy wykrzykiwane są na przykład hasła polityczne).

Kiedy treści płynące ze sceny mają na celu wywołanie przeżycia, przestrzeń teatralna jest jak gdyby trójwymiarowa w sensie abstrakcyjnym. Znajdujący się $w$ przestrzeni teatralnej ludzie nie są monolitem, stanowią odrębne jednostki przestrzenne. Wszelkie zachowania są dozwolone i każdy ma prawo do swoich wewnętrznych - intymnych i zewnętrznych reakcji. W tym sensie przestrzeń, w której znajduje się publiczność, ma tyle ośrodków, ilu jest widzów. W przypadku uczestnictwa wizualnego przestrzeń jest jednowymiarowa. Jak obraz bez perspektywy. Wszyscy widzowie ulegają jednemu rodzajowi reakcji. Nie ma jednostkowości. Jest wspólne uczestnictwo. W tym przypadku, niejako ośrodkiem przestrzeni, żywo bijącym jej pulsem są wszyscy widzowie albo raczej cała „masa ludzka”. Nie można pozbawić tej „masy" prawa do „przeżywania”. Ono też się pojawia, ale jest jednym z elementów i nie najważniejszym. Z tym, że widz ,uczestnik wizualny" jest obserwatorem. Istnieje jakby tama oddzielająca widza od sceny obrazów, od aktora. Przestrzeń dzieli się jakby na dwie części: tę dla publiczności i tę dla aktorów. Wspólnota rysuje się między publicznością,

22 J. Got, Na wyspie Guasary. Wojciech Boguslawski i teatr Iwowski 1789-1799. Kraków 1971, s. 125. 
a to, co dzieje się na scenie, ma prowokować reakcje. Można pokusić się o stwierdzenie, że istnieje pewna opozycja przestrzenna: scena - widownia i w sensie oddziaływania aktor i widz. W przypadku przeżycia wydaje się, że występuje tu inny mechanizm. Istnieje bowiem swoista jedność między aktorem - pokazującym pewne wydarzenia jakby w nich uczestniczącym a przeżywającym $i$ uczestniczącym widzem. $\mathrm{Ci}$, co demonstrują, $i$ ci co odbierają ten obraz razem uczestniczą $w$ obrzędzie. $W$ tym sensie są monolitem. W tym sensie również bariera między „sceną" a „widownią" jest zachwiana. Często jej nie ma.

Tak więc, w zależności od metody opowiadania ze sceny uzyskiwane są różne efekty reakcji u widza.

Skupiłam się w swojej pracy na pokazaniu pewnych metod oddziaływania na publiczność, mając jednocześnie cały czas przeświadczenie, że teatr to zespół złożonych czynników, że na sposób „docierania" do publiczności ma wpływ dramaturg, reżyser, aktor. (Przedstawiłam tu też dosyć jaskrawe przykłady, aby unaocznić proces reagowania widza.) Nie analizowałem też minusów, detali i odstępstw od reguł w poszczególnych wypadkach. Chodzilo mi o pokazanie biegunów i zauważalnych tendencji.

$\mathrm{Na}$ przykład teatr Meyerholda jest inscenizacyjny. Reżyser decyduje o takim, a nie innym sposobie opowiadania i prowokowania publiczności. On ma najwięcej teatralnej ,władzy". To on modeluje dramat, wprowadza do niego zmiany. Podobny mechanizm jest w przykładzie teatru Bogusławskiego.

W teatrze romantycznym istnieje współzależność między inscenizatorem a dramaturgiem, który chce sprostać wymaganiom sceny. Obydwaj są stymulowani przez publiczność. W średniowieczu (w omawianym przykładzie) - przekaźnikiem ważnych treści i symboli stają się aktorzy, z ich gestami i uczestnictwem w, ,archetypowych wydarzeniach".

Niewątpliwe "okoliczności" epoki stymulują to, co dzieje się w teatrze danego okresu i kto ma $w$ nim głos decydujący jako twórca. Określają też miejsce publiczności zarówno w płaszczyźnie przestrzennej, jak i w sferze przeżyć i odbioru. „Teatr jest zjawiskiem społecznym” - pisze Jean Duvignaud. „Na długo przedtem, zanim reżyser zaczął aspirować do roli jedynego "rzeczywistego twórcy dramatycznegor" i zanim Antonin Artaud oznajmił, że "wszelka twórczość pochodzi ze sceny«, można było stwierdzić, iż przedstawienie teatralne wyzwala wierzenia i namiętności, odpowiadające tętnu życia grup społecznych i całych społeczeństw. Sztuka osiąga stopień uogólnienia wykraczający poza ramy literatury pisanej: działalność estetyczna przeradza się $w$ działalność społeczną"23.

${ }^{23}$ J. Duvignaud, Spoleczna praktyka teatru w: Teatr w kulturze. Opracowali W. Dudzik i L. Kolankiewicz, Warszawa 1991, s. 72. 
Duvignaud kładzie duży nacisk na aktualność teatru, a poprzez owo osadzenie w rzeczywistości, w teraźniejszości właśnie na jego aspekt społeczny. I dalej czytamy o teatrze.

„Jest to jednak sztuka zakorzeniona najbardziej ze wszystkich sztuk zaangażowania $w$ żywy nurt zbiorowego doświadczenia, najbardziej czuła na wstrząsy, jakie targają życiem społecznym, będącym w permanentnym stanie rewolucji, wrażliwa na żmudne postępy wolności, która bądź posuwa się mozolnie naprzód, na poły zdławiona przeciwnościami i przeszkodami nie do pokonania, bądź dokonuje nagłych, gwałtownych skoków"24.

Wydaje się, że o takim teatrze pulsującym życiem codziennym, tym wszystkim, co niosą ze sobą czasy, w których powstaje, byla tutaj mowa. Właśnie $w$ takim sensie teatr ten podlegał różnym zmianom i ewolucjom w zależności od okoliczności epoki. Zarówno tych szczególnych - politycznych - wyjątkowych, jak i tych prowokowanych przez filozofów i artystów, ale i nierzadko wywolywanych przez publiczność i jej potrzeby.

Jeśli tak na tę sprawę spojrzymy, to $w$ tym niesamowitym ruchu, w czasie drogi, którą teatr pokonuje niejako równolegle do epoki, wraz z nią (będąc cały czas razem z człowiekiem, blisko niego) pojawiają się dwa bieguny tego ruchu. Bieguny, które już zostały nazwane: Dionizos i Apollo, sześcian i kula.

$W$ sensie przedstawiania $i$ odbioru sztuki teatralnej będzie to $z$ jednej strony żywiołowość i ekstatyczność w duchu dionizyjskim - bardzo zbliżona do pojęcia przeżycia teatralnego, o którym pisałam, i z drugiej strony: umiar, operowanie obrazem, nastawiona na opowiadanie sztuka apollińska.

Podążmy więc choć przez chwilę drogą, jaką wytyczył Friedrich Nietzsche, kiedy pisał: „Pomyślmy o naszym wlasnym zdziwieniu wobec chóru i bohatera tragicznego $w$ owej tragedii [Ajschylosa - A.D.K.], których obu nie umieliśmy pogodzić, tyleż z naszymi przyzwyczajeniami, co z tradycją, pókiśmy w samej owej dwoistości nie odnaleźli początku $i$ istoty tragedii greckiej, wyrazu dwóch ze sobą splecionych popędów artystycznych: żywiołów apollińskiego i dionizyjskiego"25.

I dalej:

„Apollo stoi przede mną jako promienny geniusz principi individuationis, przez którego jedynie prawdziwie osiągnąć można wyzwolenie w pozorze, podczas gdy mistyczny okrzyk radości Dionizosa rozsadza zaklęty krąg indywiduacji i otwiera droge do matek istnienia, do najwnętrzniejszego rdzenia rzeczy. To ogromne przeciwieństwo, otwierające przepaść między sztuką plastyczną, jako apollińską a muzyką, jako sztuką dionizyjską $(. . .)^{26}$

\footnotetext{
24 J. Duvignaud, op. cit., s. 71.

${ }^{25}$ F. Nietzsche, Narodziny tragedii w: Teatr w kulturze, op. cit., s. 314.

${ }^{26}$ F. Nietzsche, op. cit., s. 317.
} 
Jesteśmy więc u źródeł teatru, w Grecji, u źródeł, które wytyczają kierunek w przyszłość. Czy więc nasze (opisane) „przeżycia" i „obrazy” są kontynuacją tych dziedzin filozofii sztuki teatralnej?

W znaczeniu umownym nazwalibyśmy nasze przeżycie: muzyką, a teatr wizualny $\mathrm{i}$ jego oddziaływanie: obrazem plastycznym. Myślę, że brzmi to pięknie. To też jest droga interpretacji.

Pozostaje już teraz zakreślenie przestrzeni teatralnej omawianych widowisk.

Umieśćmy teatr wizualny - obraz w bryle sześcianu tak, jak chce tego Sourieau, a teatr prowokujący przeżycie wewnętrzne "wtłoczmy" do kuli.

Bo czyż nie jest tak, że w tym pierwszym wypadku wszystko, co widzimy, jest namacalne, unaocznione, konkretne jakby na wyciągnięcie ręki, a w drugim przestrzeń rozpływa się, by tworzyć sensy uniwersalne, by mówić o wrażeniach, pojęciach i uczuciach globalnych? 